\title{
Geotechnical Behavior of Clays from Ngbo Area, Eze-Aku Formation, Southeastern Nigeria in Construction
}

\author{
Mathias 0. Nweke ${ }^{1}$, Hilary N. Ezeh', Philip N. Obasi', Ikenna A. \\ Obasi $^{1}$
}

${ }^{1}$ Ebonyi state University, PMB 053, Abakaliki, Ebonyi state Nigeria

\begin{abstract}
Clays noted to be highly expansive belonging to Ezeaku Formation, southeastern Nigeria were characterized using the following geotechnical properties which included Grain size distribution, Atterberg limits, free swell, bulk density, specific gravity, cation exchange capacity (CEC), chemical composition. The chemical composition of the clays indicates low percentages of $\mathrm{Na}_{2} \mathrm{O}$ with fairly higher percentages of $\mathrm{CaO}$ and $\mathrm{K}_{2} \mathrm{O}$. The clays are plastic with liquid limit (LL) of 58.8 to 72.8, plastic limit (PL) of 24.6 to 30.1 and plasticity index (PI) of 35.5 to 45.8 . They classify as inorganic clays of high plasticity $(\mathrm{CH})$ according to USCS and as A-7-6 according to AASHTO classification systems. Plots of LL against PI show that the study clays are predominately illite with low presence of montmorillonite. The clays showed high specific gravity, which may be a reflection of their high iron content. This is an indication that the clay material is unsuitable for use as highway such as sub-base, base course and sub-grade materials and airfield pavement bases unless improved. Adequate road design and heavy compaction with necessary stabilization material will boost strength and stability of the clays for all purposes, especially as a base course material.
\end{abstract}

Keywords: Clay, Effium, Ezeaku Formation, Ngbo, Southeastern Nigeria

\begin{abstract}
Introduction
Clays and clay soils are highly variable and complex materials but because of their universal availability and low cost, they are frequently used for engineering purposes. Clay or clay soil at a particular locality, however, may be partly or wholly unsuitable from the point of view of construction. In such instance that it exhibits poor quality, it is important to alter the properties of this material and thus improve its suitability as construction material. Most often clays are used in situ (subgrade and foundation) or as aggregates in projects which include roads and highways, dams, bridges and buildings. The severities of the collapsed roads (see Fig. 1) are quite severe, for instance, along Ezzangbo-Effium (within the Ebonyi State territory). There are about 100 failed spots, locally referred to as 'pot-holes', within distance ranging from a few metres to tens of metres long. Remediation or reconstruction of failed is often
\end{abstract}

an expensive venture hence the need for adequate assessment and stabilization (where necessary) prior to construction to ensure safety and durability of geotechnical projects in the area

The term "clay" generally refers to clay minerals predominated Grim (1968), fine-grained materials, with particle size less than $0.002 \mathrm{~mm}$. Other minerals associated with clay minerals in clays may include quartz and feldspar, as well as detrital materials that were eroded from the earth's surface. Clays with montmorillonite as predominated clay minerals usually give the clay its swelling characteristic. They swell to levels that far exceed their original volume (Grim, 1968). The interest in clay arises from the behaviour of soils under load as a result of engineering structures such as roads, dams, bridges and buildings.

This article is published under the terms of the Creative Commons Attribution License 4.0

Author(s) retain the copyright of this article. Publication rights with Alkhaer Publications.

Published at: http://www.ijsciences.com/pub/issue/2015-03/

Article Number: V420150321; Online ISSN: 2305-3925; Print ISSN: 2410-4477 


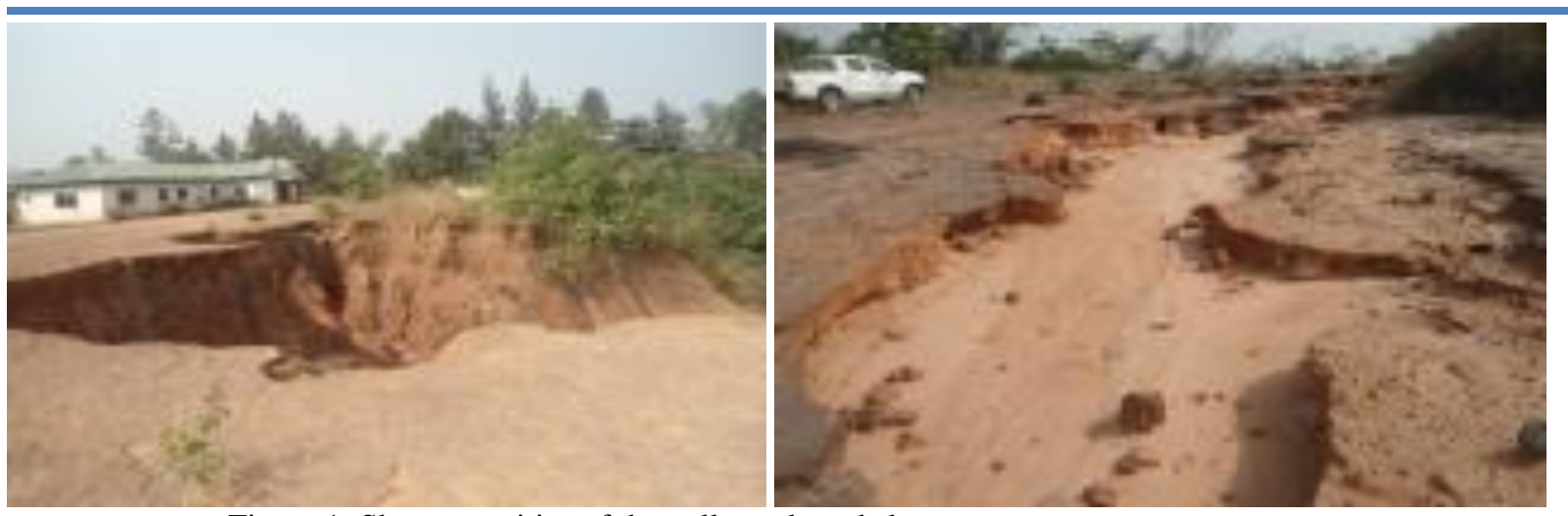

Figure 1: Show severities of the collapsed roads 1

According to Wheeler, et al. (2003), swelling characteristics of clays depend on other factors such as initial water content and suction. However, expansive clay literature reviews according to (Chen, 1975), (El-Sohby and Rabba, 1981) and (Dhowian et al., 1990) identify liquid limit, clay mineral type, clay content, plasticity index, initial moisture content the initial dry unit weight as the important swell indicating properties. According to Samuels and Cheney (1974), soils expand when trees that were rooted in them fell prior to construction, giving rise to increased soil moisture and swelling.

Clays occur abundantly in the sedimentary basins of southeastern Nigeria. Sedimentary processes including alternating transgression and regression cycles led to the formation of alternating sequences of clay deposits, shales and other sedimentary materials within the southeastern Nigeria sedimentary basins (Ogbukagu, 1982). Chemical composition and mineralogical composition as well as the particle size distribution according to some workers such as Inyang et al. (2007) are also important properties that directly control the plasticity and swell potential of the clays. The problems of swelling in clays have caused damages to mainly lightly loaded civil engineering structures such as buildings and most highways that traverse or were constructed on the clay soils. The damage is primarily a result of excessive water infiltration into subsoil, or rising water table, causing the excessive movement of the floor slab, the foundation and the load bearing members. Rising groundwater may be caused by leaking services and over-irrigation in the expanding urban areas (Al-Sanad et al. 1990). Most of the geotechnical problems have a lot to do with the nature of the soils which can be accessed from the knowledge of their mineralogical composition, Atterberg limit values and resulting strength properties. Improper site investigation and the lack of appreciation of the swelling potential of the underlying soils may have caused these damages.

Previous investigations (Ogbukagu, 1978 and Akpokodje et al. 1991) have so far been carried on the mineralogical compositions of some clay from Asu Group (mid-Albian) and Eza-Aku Formation, southeastern Nigeria. This paper determines whether all the clayey soil of Ngbo area of Eze Aku Formation exhibit similar swelling characteristics, investigates the sources of the clay minerals and examine the relevance of the available swell-versus property correlation for the clays. The importance of this study is increased by the recent construction of roads which collapses soon after construction and the effect of erosion within these areas.

\section{Geomorphology}

Ngbo in Ohaukwu LGA is geographical located between latitude $6^{0} 15^{\prime} \mathrm{N}$ and $6^{0} 20^{\prime} \mathrm{N}$ and longitude $8^{0} 05^{\prime} \mathrm{E}$ and $8^{0} 10^{\prime} \mathrm{E}$ covering a total area of about $81 \mathrm{~km}^{2}$. The areas were accessed through EnuguAbakaliki Express road and Ezzanbgo Effium road through a network of tarred roads. During the fieldwork, vehicles, motorcycles and footpaths were employed to aid accessibility and movement through the outcrop locations and sample collections. The vegetation of Ngbo and its environs is luxuriant vegetation of tropical rainforest. Its vegetation is densely populated with grasses and trees of different sizes in the area. The area is marked by undulated range of shale outcrops and the shales are either greyish or reddish brown in colour depending on its content and degree of weathering. The area had $400 \mathrm{ft}$ as its highest contour and $100 \mathrm{ft}$ as its lowest contour above sea level.

The climate of the study area is of humid tropical climatic region. It experiences one rainy season and one dry season (eight months of rainfall and four months of dryness). Harmattan is felt between December \& January. The mean annual temperature stands at $28^{\circ} \mathrm{C}$. Humility in this area is about $50-60 \%$ P.a. The mapped area has a mean annual rainfall of $2500 \mathrm{~mm}$. Rainfall is highest in September and lowest in January. The drainage system of the study area is dendritic in pattern, as a function of lithologic control. The study area is mainly drained by Izhia River and Ebonyi River with few minor drainage flows. All these, both the major and minor drainage system flow eastward to join the Cross River Somewhere outside the study area.

\section{Geology}

Ngbo of Ezeaku Formation of Southeastern Nigeria, lie within the southern Benue Trough (see Fig. 2). 
The Benue Trough is a major structural basin of subsidence, which originated as a result of basement fragmentation and rifting during the Cretaceous continental separation of Africa and South America. It was described as an abandoned rift basin "aulacogen" which developed as a result of intermittent mantle plume activities and sedimentation accompanying continental extension. The first marine transgression in the trough is generally believed to have started in the mid-Albian period with the deposition of the Asu River Group made up of predominantly shales and localized development of sandstone, siltstone and limestone facies (Hoque and Nwajide, 1988 and Grant, 1971). The group has average thickness of about $2000 \mathrm{~m}$ and rests unconformable on the Precambrian Basement. The stratigraphy of the study area consists of deposited in alternating transgressive and regressive phases. Murat (1972) was of the view that the EzeAku Shale shows deposits of marine condition in a tectonically controlled basin (the Abakiliki Trough). He believed that sandstone deposits mark a period of regression, while the shale deposits indicate a period of transgression. The Eze-Aku Formation was deposited in the Turonian transgressive phase but in a shallow marine environment. The lithologies include shale, sandstones, and calcerous sandstones. The fossils in this Formation include vascocerastids, pelecypods, gastropods, echinoids, fish teeth, decapod, and plant fragments (Reyment, 1965). The expansive clays encountered in Ngbo areas and used for the study are dark brownish superficial clays derived from beds of shale, limestone and pyroclastic in the underlying cretaceous bedrock, by processes of weathering and erosion

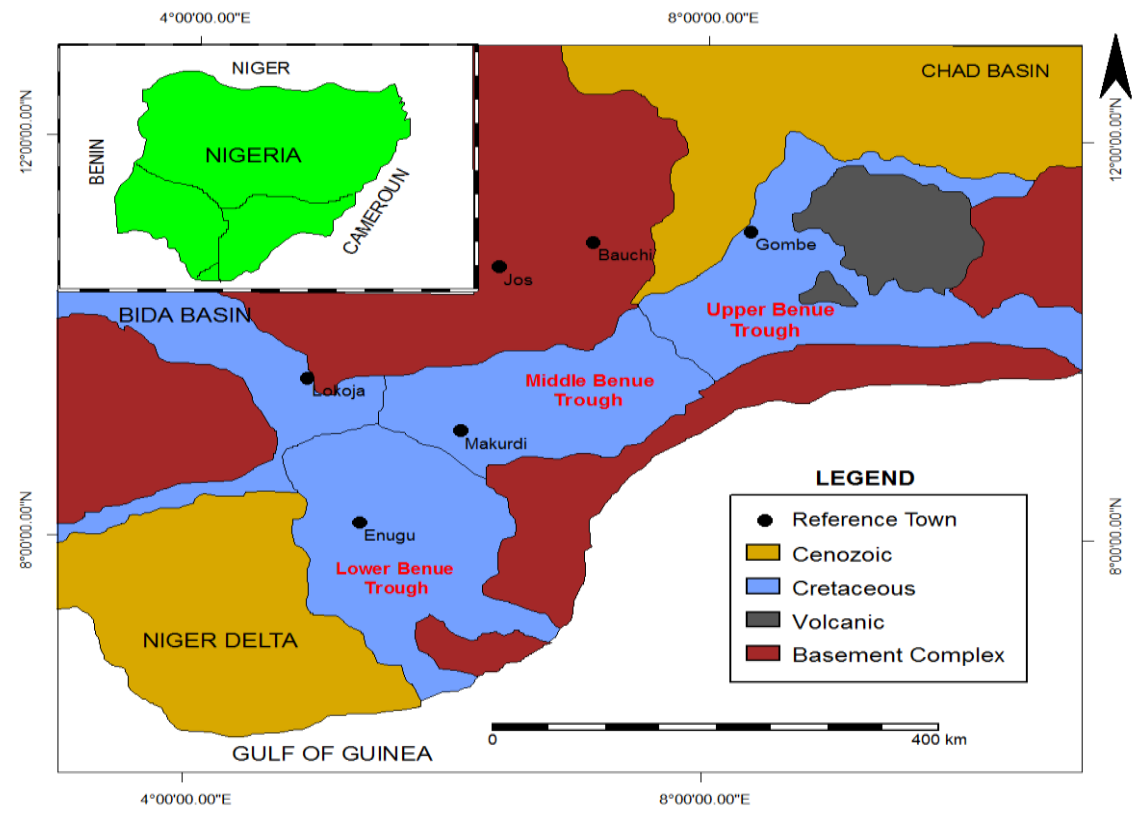

Figure 2: Map of the Benue Trough of Nigeria (Modified from Obaje et al., 2013)

\section{MATERIALS AND METHODS}

Sampling

The studied clay samples were taken from Eze Aku Formation (Fig. 1). These samples are the in-situ weathered products of the Turonian age. They are darkish brown weathered materials, range from 1-3 m thick and are generally covered by an upper layer (0.2- $1 \mathrm{~m}$ thick) of stony/rock fragmentary soil. The lateritic over-burden varies from 2-6 $\mathrm{m}$ and the clay layers are 2-5 m thick. In some locations, the samples are dark grey in color, with brownish upper regolith as a result of tropical weathering. Care was taken when sampling to ensure that fresh samples were taken and that such samples were representative of the materials to be assessed. The clay samples were packaged in polyethylene-sacks, clearly labelled and taken to the laboratory at National Steel Raw Material Exploration Agency, Kaduna for testing.

\section{Laboratory tests}

Geotechnical laboratory tests such as grain size distribution, Atterberg Limits, specific gravity, free swell and bulk density were carried out on the samples. An IVT-20 computer-automated X-ray fluorescence (XRF) spectrometer was used for bulk chemical analysis of the clay samples. The clay samples were prepared in accordance with outline given in Kenigan (1971). The method proposed by Hendershot and Duquette (1986) was used in this study to determine the exchangeable cations. These were in accordance to the methods given using the standard procedures specified by Lambe (1951) and British Standard Institution (1975). The hydrometer tests and Atterberg limits tests were carried out using the standard procedures specified by the American Society for Testing and Material (1979). Free swell index (FSI) an important index property of expansive soils, which indicates the innate potential the soil has for swelling, was also carried out according to Holtz and Gibbs (1956). 


\section{RESULTS AND DISCUSSION}

\section{Chemical composition}

The results of chemical analysis of the clays samples are presented in Table 1. These results are similar to those obtained by other authors such as Akpokodje et al. (1991) for clays from southeastern Nigeria. Higher
$\mathrm{Na}_{2} \mathrm{O}$ contents in some samples $(1.48-1.98 \%)$ than the $(0.68 \%-0.98 \%)$ noted in some samples suggest that the former may be of slightly different clay mineral composition as they were from different geologic

Table 1: Chemical Composition of the study clay

\begin{tabular}{ll}
\hline \multicolumn{2}{c}{ Composition w\% } \\
\hline Chemical Oxides & Ngbo clay \\
\hline & \\
$\mathrm{SiO}_{2}$ & $50.10-58.96$ \\
$\mathrm{Al}_{2} \mathrm{O}_{3}$ & $19.90-25.08$ \\
$\mathrm{Fe}_{2} \mathrm{O}_{3}$ & $3.80-4.67$ \\
$\mathrm{TiO}_{2}$ & $1.10-2.10$ \\
$\mathbf{C a O}$ & $1.00-5.42$ \\
$\mathrm{MgO}$ & $0.32-2.02$ \\
$\mathrm{~K}_{2} \mathrm{O}$ & $0.52-1.40$ \\
$\mathrm{Na}_{2} \mathrm{O}$ & $0.68-1.98$ \\
$\mathrm{MnO}$ & $2.00-3.34$ \\
\hline
\end{tabular}

The relatively high percentages of $\mathrm{K}_{2} \mathrm{O}(0.52-1.40 \%)$, suggests illite as the dominant clay minerals. The appreciable $\mathrm{CaO}$ in clays may possibly be attributed to the occurrence of carbonates such as calcite in fairly large amounts in these clays. In all the clays studied, the $\mathrm{Na}_{2} \mathrm{O}$ values are lower and $\mathrm{K}_{2} \mathrm{O}$ and $\mathrm{CaO}$ values higher. The results of the grain size distribution analyses of the clay samples are presented in Table 2. The samples are characterized by high proportion (44-48\%) of silt size fraction and (34-46\%) of clay size fraction. The colloidal content of the studied clays (34-46\% clay fraction) is thought to be a significant factor in the plasticity and swelling properties of these clays.

Table 2: Results of Cation exchangeable capacity and hydromteter test

\begin{tabular}{|c|c|c|c|c|c|c|c|c|c|c|c|}
\hline \multicolumn{12}{|c|}{ Cation Exchangeable Capacity meq/100 g } \\
\hline & $\mathrm{LI}$ & L2 & L3 & L4 & L5 & L6 & L7 & & L9 & L10 & ave \\
\hline $\mathrm{Ca}^{2+}$ & 33.2 & 36.3 & 38.6 & 32.3 & 30.1 & 32.9 & 28.8 & 34.8 & 35 & 28.98 & 33.1 \\
\hline $\mathbf{k}^{+}$ & 1.49 & 2.36 & 2.07 & 2.69 & 3.66 & 2.12 & 2.31 & 2.07 & 2.67 & 2.19 & 2.4 \\
\hline $\mathbf{N a}^{+}$ & 12.3 & 16.6 & 12.8 & 11.1 & 13.5 & 12.4 & 16.5 & 12.3 & 14.8 & 12.79 & 13.5 \\
\hline \multirow[t]{2}{*}{$\mathbf{M g}^{2+}$} & 4.3 & 5.7 & 5.3 & 4.9 & 5.6 & 4.9 & 6.7 & 5.3 & 5.4 & 6.7 & 5.5 \\
\hline & \multicolumn{11}{|c|}{ Results of Hydrometer Analysis \% } \\
\hline Sand & 18 & 14 & 10 & 8 & 10 & 20 & 29 & 20 & 14 & 11 & 15.4 \\
\hline Silt & 48 & 46 & 44 & 52 & 48 & 42 & 38 & 48 & 48 & 51 & 46.5 \\
\hline Clay & 34 & 38 & 46 & 40 & 42 & 38 & 41 & 42 & 38 & 38 & 39.7 \\
\hline Free Swell\% & 60 & 63 & 59 & 55 & 62 & 56 & 60 & 50 & 58 & 58 & 58.1 \\
\hline
\end{tabular}

The proportions of sand are less than $20 \%$ for all the studied clays (sand fraction). The Activity (Skempton, 1953) values of the clays (Table 2) suggest that the clays are possibly calcium rich, rather than sodium rich. The results of the Atterberg limits tests the clays as shown in Table 2 indicates that the clays have relatively high plasticity (relative to clays of low plasticity with $\mathrm{LL}<50$ ). The high average liquid limit value of $63.6 \mathrm{t} \%$ indicates a sample with a high water retention capacity. Atterberg plasticity index (API) average value of $36.75 \%$ shows that the sample is plastic over a wide range of moisture content. This also corroborates the high alkali content of 0.68-1.98 $\mathrm{Na}_{2} \mathrm{O}$ and 0.52$1.40 \mathrm{~K}_{2} \mathrm{O}$ in the sample. A plot of the LL versus the PI on the Casagrande plasticity chart shows that all the clays plot above the A-line (see Fig. 4), with some clustering and perhaps indicating materials of similar clay mineralogy. The high plasticity index as noted in the plot reveals the clay's potential for great volume change characteristics. The high proportion (44-52\%) of silt size fraction makes the sample material unsuitable for wide ceramic applications. 


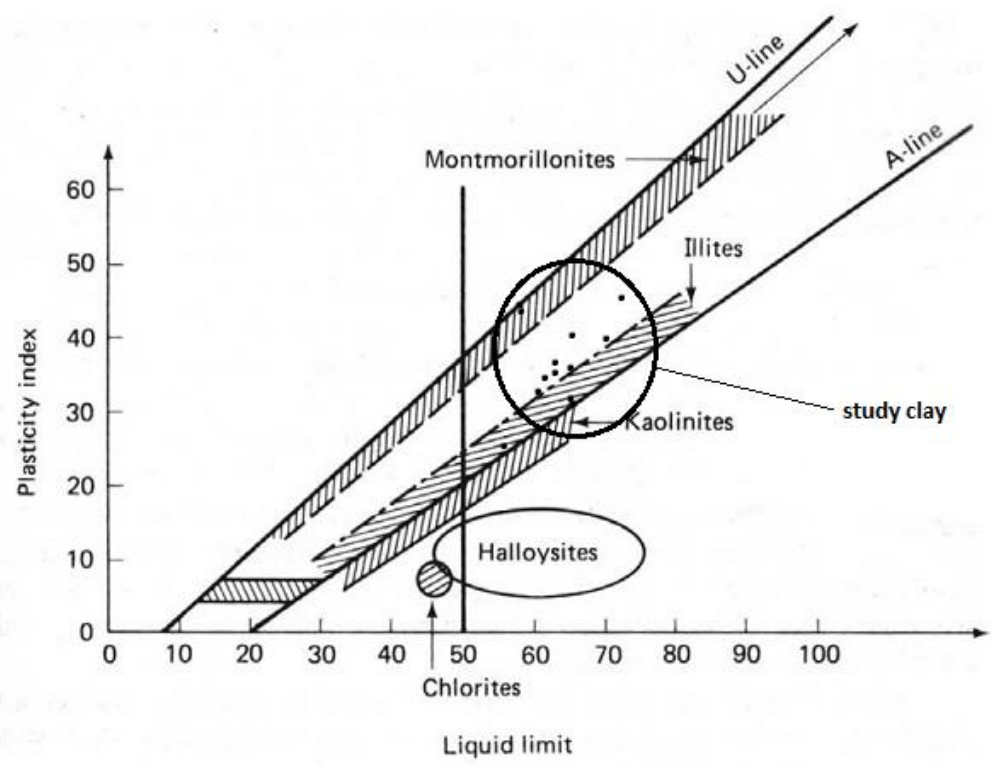

The high plasticity of these clays can perhaps be attributed to high clay size fractions $(34-46 \%)$ and the presence of low percentage of montmorillonite, most probably the calcium variety. The plot indicates that they study clay are predoiminantly illite as few of the clays plotted close to montmorillonite. Obaje et al (2013) noted that most common clay mineral of marine sedimentary rocks is illite, which suggests that montmorillonite is converted to illite by a slow reaction with abundant $\mathrm{K}+$ of sea water. They concluded that clay minerals are characteristic of particular environments of weathering, and a study of clays might make possible a reconstruction of the paleoenvironment where they were formed or ultimately deposited. The clay can be associated with less humid climates. The clays as plotted on the Casagrande plasticity chart can be classified as inorganic clays of high plasticity $(\mathrm{CH})$ according to the Unified Soil Classification System (USCS) and as A-7-6 according to the America Association of State
Highway and Transportation Officials (AASHTO) classification system. ASTM 1982 indicates that soils with a LL greater than 10, PI greater than 10 and greater than $35 \%$ finer than $75 \mu \mathrm{m}$ may be expansive and thus subsequently rated as very poor for potential use as sub-base, base course and sub-grade materials. This is an indication that the clay material is unsuitable for use as highway and airfield pavement bases unless improved. The results of the specific gravity $G_{\mathrm{s}}$ tests for the clays shown in Table 3 are between 2.42 and 2.64. From the results, the $\mathrm{G}_{\mathrm{s}}$ are high although fairly variable. The low values (less than 2.42) were obtained from clays from Ezeaku Formation can be attributed to the presence of gypsum which were noted from the analysis of their chemical composition especially in the samples from Ekwashi areas. The high $\mathrm{G}_{\mathrm{s}}$ noted in some samples might possibly be a reflection of high content of $\mathrm{Fe}_{2} \mathrm{O}_{3}$

$(3.80-4.97 \%)$

Table 3: Results of Atterberg limit test, specific gravity, bulk density and calculated Activity value

\begin{tabular}{llllllllllll}
\hline Parameters & L1 & L2 & L3 & L4 & L5 & L6 & L7 & L8 & L9 & \multicolumn{2}{c}{ Ave. } \\
\hline Specific gravity & 2.54 & 2.56 & 2.42 & 2.64 & 2.6 & 2.2 & 2.45 & 2.6 & 2.54 & 2.34 & 2.48 \\
Bulk density & 1.55 & 1.68 & 1.67 & 1.52 & 1.45 & 1.7 & 1.57 & 1.59 & 1.45 & 1.53 & 1.57 \\
Plastic Limit & 24.8 & 24.6 & 30.1 & 25 & 27 & 34 & 27 & 30 & 32 & 28 & 28.25 \\
Liquid limit & 66 & 58.8 & 70 & 62.4 & 72.8 & 65 & 62 & 56 & 60 & 63 & 63.6 \\
Plasticity index & 41.2 & 44.2 & 39.9 & 37.4 & 45.8 & 31 & 35 & 26 & 32 & 35 & 36.75 \\
Activity & 1.21 & 1.16 & 0.86 & 0.9 & 1.09 & 0.81 & 0.85 & 0.63 & 0.84 & 0.92 & 0.92 \\
\hline
\end{tabular}

\section{Swelling characteristics and its challenges}

The results of the free swell tests for the clays are shown also in Table 3. Authors such as Chen (1988) and Hossain et al. (1997) identified LL as one of the important swell indicating properties, others being the clay mineral type, clay content, plasticity index and exchange capacity. They also attempted at predicting potential swell percent from one or more of these parameters using Van der Merve (1964) chart. The results show the swell potentials of Asu River Group (Cretaceous) clays as high. In the vicinity of Ekwashi, the clays of Ezeaku Formation were highly fractured and fissured and these discontinuities may have contributed to the relative high secondary permeability of the clay mass. Under natural conditions, unexposed to weathering, the 
clays (cretaceous in age) at depth are hard and plastic and exhibits high swelling characteristics. The relatively higher quantities of calcite $(3.42 \%)$ in clays of Imo Formation (Tertiary in age) may have also accounted for their low swelling potential. The clays are unusual in having both high carbonate and high silt contents and therefore tend to exhibit high undrained and drained strengths.

According to Okagbue (1989), the swelling of a soil is dependent on its mineralogical composition, the volume fractions of such minerals in the soil and the physiochemical environment to which the soil is exposed. According to Morgenstern and Balasubramonian (1980), the presence of sodium and calcium ions, among other factors, makes swell to be a potential dependent on the relative concentration of these cations, because the $\mathrm{Ca}^{2+}$ cation limits the swelling of montmorillonite, while the $\mathrm{Na}^{+}$cation enhances it. The presence of non-expansible clays such as illite and kaolinite in study clays may in part be responsible for the low swelling capacity of the clays. Soil improvement is meant here from the point of view of road construction and concerns mainly on increase in the bearing capacity and strength as well as reduction in the plasticity and linear shrinkage

\section{Summary and Conclusions}

This study evaluated the physical and chemical properties of some clays from southeastern Nigeria. The chemical compositions indicate that the values of $\mathrm{Na}_{2} \mathrm{O}$ are lower while those of $\mathrm{K}_{2} \mathrm{O}$ and $\mathrm{CaO}$ are higher. Calcium and sodium ions are the main exchangeable cation with calcium ion as the dominant cation. The clays exhibited low exchange capacity of $10.8 \mathrm{meg} / 100 \mathrm{~g}$ to $16.4 \mathrm{meg} / 100 \mathrm{~g}$. The clays in their natural state possess relatively high plasticity with LL of 58 to 72.8 , PL 24.6 to 30.1 and PI 35.5 to 45.8 . This qualitative prediction agrees roughly with the results of laboratory free swell tests, which show the clays to possess fairly high free swell values of 55 to $63 \%$. The swelling properties are thought to reflect the presence of active clay mineral such as montmorillonite. High $\mathrm{G}_{\mathrm{s}}$ values (2.42 to 2.64) were recorded for the studied clays in their natural conditions and could be attributed to high percentages of $\mathrm{Fe}_{2} \mathrm{O}_{3}$. According to AASHTO (1961) it may be possible to use soils that have been rated as unsuitable for construction purposes, but that requires application of extreme caution. Also, adequate road design and heavy compaction with necessary stabilization material will boost strength and stability of the clays for all purposes, especially as a base course material. The study clays, especially those clays with high percentage of kaolinites, can be used in pharmaceutical preparations of intestinal adsorbent drugs and other therapeutical applications and as drilling mud when beneficiated.

\section{Acknowledgements:}

The authors are highly indebted to staff of National Steel Raw Material Exploration Agency, Kaduna for their assistance in the completion of this work.

\section{References}

I. Akpokodje, E.G., Ololunfemi,B.N. and Etu-Efeotor, J.O., 1991. The composition and physical properties of some ceramics and pottery clays of Southeastern Nigerian. Journal of Min. and Geol., Vol.27, P.1-7

II. American Society for Testing and Material, 1979. Annual Book. ASTM Standard, Part 19, Philadelphia http://dx.doi.org/10.1016/0043-1354(80)90051-2

III. British Standard Institution, 1975. Methods of testing soils for Civil Engineering purpose, Bs 1377.

IV. Bell, F.G., 1976. The influence of the mineral content clays on their stabilization of cement. Bulletin of the Association of Engineering Geologists, Vol. Xiii, No. 4, P. 267-277. http://dx.doi.org/10.2113/gseegeosci.xiii.4.267

V. Chen, F.H., 1988. Foundations on expansive soils. $2^{\text {nd }}$ edition, Elsvier Scientific Amsterdam, Netherlands.

VI. Grant, N.K., 1971. The South Atlantic Benue Trough and Gulf of Guinea Cretaceous triple junction. Geol. Soc. Am. Bull., Vol. 82, P. $2295 \quad$ - 2298. http://dx.doi.org/10.1130/0016-

7606(1971)82[2295:sabtag]2.0.co;2

VII. Grim R.E., 1968. Clay Mineralogy. $2^{\text {nd }}$ Edition,McGarwHill, New York, 596pp.

VIII. Hall, P.L., 1993. Mechanism of overpressuring: an overview In: Geochemistry of clay-pore fluid interactions edited by Manning,D.A.C., Hall,P.L. and Hughes, C.R., Chaman and Hall London,P.265-309

IX. Holtz, W.G. and Gibbs, H.J., 1956. Engineering properties of expansive clay. Trans ASCE, vol.121, P. $641-663$.

X. Hoque, M. and Nwajide, C.S., 1988. Tectonosedimentological evolution of elongated intracratonic basin (Aulacogen): The case of Benue Trough Nigeria. Journal of Min. Geol., Vol. 21, P.12 - 18.

XI. Hossain, D., Matshal, M.I. and Sadagah B., 1997. Swelling characteristics of Madinoh clays. Journal of Engineering Geology, vol. 30, p. $205-220$

XII. Inyang, H.I., Bae, S., Mbamalu, G. and Park S., 2007. Aqueous polymer effects on volumetric swelling of $\mathrm{Na}$ montmorillonite. Journal of Material in Civil Engineering (ASCE), vol. 19., $\quad$ No.1, P.84-90 http://dx.doi.org/10.1061/(asce)0899-1561(2007)19:1(84)

XIII. Reyment, R.A., 1965. Aspect of Geology of Nigeria. Ibadan University press. $145 \mathrm{pp}$

XIV. Morgenstern, N.R. and Balasubramonian, B.I., 1980. Effects of pore fluid on the swelling of clay shale. Proceedings of the fourth International conference on Expansive soils. Denver, Vol.1, P.190-205.

XV. Okagbue, C.O., 1989. Geotechnical and environmental problems of the Niger-delta. Bulletin of the International Assoc. of Engineering Geology, No. 40, P.199-128. http://dx.doi.org/10.1007/bf02590349

XVI. Skempton, A., 1953. The colloidal activity of clays. Proc. $3^{\text {rd }}$ Int. Conf. Soil Mech. Foundation Eng., Zarich,1:57-61.

XVII. Tourtelot, H. A., 1974. Geologic origin and distribution of swelling clays. Bulletin of he Association of Engineering Geologist, Vol. V1, No. 4, P. 259-273.

XVIII. Van der Merve, D. H. 1964. The production of leave from the plasticity index and the percentage of clay fraction. Civil Engineering in South Africa.

XIX. Wright, J.B., 1976. Origin of the Benue Trough. A critical review In: C. A. Kogbe (ed.) Geology of Nigeria. Elizabethan Publishing company, Lagos- Nigeria, P.187-295. 